\author{
Sławomir Futyma \\ Uniwersytet im. Adama Mickiewicza w Poznaniu \\ E-MAIL: futek@amu.edu.pl
}

\title{
O niektórych aspektach etosu edukacyjnego i konsumpcji
}

\section{STRESZCZENIE}

Artykuł opisuje dokonujące się zmiany w postawie osób „uprawiających naukę”. Zmiany te dotyczą rozumienia, czym jest wiedza, a tym samym, czemu ta wiedza ma służyć. W niniejszym tekście zwraca się uwagę na fakt, iż elementem często decydującym o wartości przekazywanej wiedzy jest czynnik ekonomiczny. Ten nowoczesny utylitaryzm zawłaszczył ludzi wraz z ich ambicjami, umiejętnościami. Stąd w niniejszej refleksji odnajdziemy rozważania dotyczące: wartości wiedzy, postaw ludzi nauki, roli i miejsca edukacji we współczesnym świecie oraz takich czynników, które modyfikują współczesny kształt edukacji i jej funkcjonariuszy, jak: egoizm czy też racjonalność konsumencka.

SŁOWA KLUCzOWE: edukacja, konsumpcja, etos edukacyjny, rynek edukacyjny.

Jesteśmy przekonani, że te funkcje, które w naszej części Europy spetniała tradycyjnie inteligencja - formacja społeczna tylko dla tego regionu charakterystyczna - będą musiały być nadal wypetniane przez jakieś grupy w naszych przekształcających się społeczeństwach. Chcemy, żeby ci, którym wypadnie grać tę rolę, byli świadomi tradycji humanistycznych, umieli $i$ wiedzieli więcej niż tego wymaga doraźny sukces $i$ tym sensie stanowili pewna przeciwwage dla bardzo pragmatycznie nastawionej większości. /Prof. Jerzy Axer/ (Bikont, 200o)

Ta poniższa, krótka analiza jest próbą spojrzenia na współczesny świat, w którym ludzie często dostrzegają swoje miejsce jako swoiste zawieszenie między zachłannością a odpowiedzialnością. Artykuł ten, to spojrzenie na świat, w którym gospodarka zawłaszczyła ludzi wraz z ich ambicjami, umiejętnościami i sprawiła, że takie zjawiska, jak m.in. edukacja, znalazły się w obszarze jej bezpośredniego oddziaływania. Refleksja ta nakreśla spotkanie dwóch światów, świata ekonomi, opłacalności, świata, w którym człowiek przeliczany jest przez produkt krajowy brutto, świata opisywanego w kategoriach inżynierii, ze światem natury, światem wartości wynikającym z człowieczeństwa. 
Siła tego pierwszego świata, świata ekonomii, i powierzchowna atrakcyjność jego oddziaływania sprawia, że urzędnicy instytucji edukacyjnych stają się często narzędziami w rękach ekonomistów, mającymi przyczynić się do wzrostu gospodarczego. Tym samym, efektem procesu edukacyjnego mają być kolejne pokolenia konsumentów, którzy to codzienność swoją realizują na smyczy polityki ekonomicznej. (Pojęcie edukacji, którym się tutaj posługuję, opisałem w książce WolNego RYNKU IMPLIKACJE DLA EDUKaCjI zob. Futyma, 2001).

\section{Wartość wiedzy}

Na początku czerwca 2015 roku w mediach na całym świecie pojawiła się zaskakująca wiadomość dotycząca tego, że uniwersytety państwowe Japonii rozpoczęły wygaszanie kierunków humanistycznych i społecznych. Szkolnictwo wyższe ma skupić się na naukach technicznych i przyrodniczych, można wyczytać z dokumentów, a niniejsze działania, według japońskich analityków rządowych, mają znacznie przyczynić się do wzrostu gospodarczego.

O działaniu tym obwieścił w stosownym dokumencie japoński minister edukacji - Hakubun Shimomura. Chociaż decyzja ministra miała charakter jedynie zalecenia, jednak w tym czasie wprowadziło ją dwadzieścia sześć spośród sześćdziesięciu uczelni wyższych, a siedemnaście kolejnych zrezygnowało z przeprowadzania rekrutacji na kierunki humanistyczne (Strawiński, 2015).

Czas zatem na wskazanie celu poniższej analizy, który to zostanie wyrażony w postawionych pytaniach. Odpowiedzi na te pytania zostaną sformułowane w postaci krótkiej analizy zjawiska edukacji, jej roli społeczno-politycznej, ról, jakie pełnią urzędnicy tychże instytucji, i możliwych do zaistnienia konsekwencji obranych rozwiązań.

Oto kilka pytań: jakie konsekwencje mogą wynikać z przyjęcia ekonomicznego kryterium opłacalności w sferze formułowania oferty edukacyjnej? Skąd wynika sytuacja „ekonomizacji edukacji” oraz bezkrytyczne przyjmowanie takiego działania spotykane u ludzi odpowiedzialnych za formację przyszłych obywateli? Dlaczego świat wiedzy rezygnuje z historycznej refleksji poświęconej działaniom, jakie w historii podejmował człowiek w rozmaitych płaszczyznach swego funkcjonowania, oraz jakie tego będą konsekwencje? Czy wszystkie działania ludzkie da się przeliczyć na produkt krajowy brutto? Jak zatem wygląda etos współczesnej edukacji i jej funkcjonariuszy, w sytuacji kiedy świat chce konsumować bez odpowiedzialności? A może ci, którzy doprowadzili do takiego stanu rzeczy oraz podejmują takie decyzje, okazują się wybrakowanymi produktami wadliwego procesu edukacyjnego? 


\section{Edukacja skonsumowanego egoizmu}

W procesie wikłania edukacji w grę rynkową, gdzie traktuje się ją jako narzędzie konstruowania wzrostu gospodarczego, a tym samym narzędzie inżynierii społecznej, upatruję poważne zagrożenie związane, między innymi, z próbą redukcji narzędzi poznawczych, jakie są dostarczane człowiekowi dla zrozumienia siebie jako części złożonej struktury świata. Usytuowanie edukacji w przestrzeni gospodarczej jest porażką współczesnej inteligencji, a także posiada daleko idące konsekwencje, z którymi będą się musiały zmagać następne pokolenia.

Edukacja krojona na miarę rozwoju gospodarczego zaczyna przypominać gada pożerającego swój własny ogon. Chce się wprost użyć słów José Antonio Mariny, który w książce Porażka InTEligenCjI CZYli gŁuPota w TeoRII I PRAKTYCE napisał, co następuje:

Inteligencja ludzka ponosi porażkę, kiedy nie jest w stanie... zrozumieć, co się dzieje (czy też - co się z nami dzieje), kiedy nie potrafi rozwiązać problemów uczuciowych, społecznych lub politycznych; kiedy systematycznie popełnia błędy, kiedy obiera sobie absurdalne cele lub obstaje przy nieskutecznych środkach (Marina, 2010, s. 9).

Sprowadzenie problemów ludzkości do określonego poziomu konsumpcji w celu podniesienia wzrostu gospodarczego jest takim działaniem „człowieka intelektualnie okaleczonego" w procesie wychowania przez system społeczno-polityczny czy też ekonomiczny, chcącego rachunkiem ekonomicznym załatwić problemy kulturowe czy też emocjonalne. Obecnie kształtowanie oblicza edukacji jest, niestety, związane z podejściem do zagadnienia sprzedawania wiedzy czy też określonych umiejętności przez przedstawicieli instytucji edukacyjnych - edukatorów. To, niestety, wyryło głębokie skazy na obliczu edukacji. Na przykład, w imię atrakcyjności procesu edukacyjnego i jego poprawności politycznej, wiele instytucji edukacyjnych rezygnuje z kształtowania poczucia tożsamości jako podstawy kreowania człowieczeństwa, a tym samym pozbawia siebie podstawowego narzędzia wychowawczego w kreowaniu przyszłych obywateli.

Wpisanie edukacji w logikę gospodarczą wynika bezpośrednio z orientacji intelektualnych edukatorów, funkcjonariuszy instytucji edukacyjnych, będących następstwem ukształtowanego etosu zawodowego. Etos, o którym mowa, podobnie jak pojęcie „habitus”, o którym pisze P. Bourdieu, to wynik interioryzacji postaw, tendencji czy też uwewnętrznionych dyspozycji, które to wprowadzane są w sferę naszych ludzkich nawyków, emocji. To oceny reakcji emocjonalnych, powstających w wyniku więzi z wartościami (Kłoskowska, 1990, s. 9). W końcu pojęcie „habitus”, według P. Bourdieu, to: 
system ograniczonych lub psychicznych dyspozycji i nieświadomych schematów myślowych, postrzeżeń i działań, stanowi właśnie czynnik sprawiający, że osoby, działające w poczuciu mocno ugruntowanego złudzenia twórczości, nieprzewidywalnej, oryginalnej i swobodnej improwizacji, mogą jednak produkować myśli, postrzeżenia i akty zachowania zgodne z obiektywną prawidłowością. Dzieje się tak, gdyż sam habitus został zrodzony w warunkach obiektywnie określonych tymi prawidłowościami, a zarazem przez te warunki (Bourdieu, Boltanski, Castel, Chamboredon, 1965, s. 23).

Tak też system gospodarczy dokonał spustoszenia w sferze psychicznych dyspozycji i nieświadomych schematów myślowych, postrzeżeń i działań. W wyniku tego spustoszenia etos określonych grup społeczno-zawodowych stał się przestrzenią zaakceptowanego stylu życia, który opiera się na przyjętej określonej hierarchii wartości. W tym wypadku, konsumującego się egoizmu.

Ponieważ etos artykułowany jest przez określone sytuacje społeczne, które nie wpisują się w proste działanie arytmetyczne, należy zwrócić uwagę na pojawiające się różnice uwydatniające pęknięcie pomiędzy nim - etosem - a praktyką dnia codziennego, która to weryfikuje posiadane przekonania moralne. Etos ukazuje się nam jako czynnik pośredniczący pomiędzy faktycznie funkcjonującym systemem a zbiorem indywidualnych lub grupowych przekonań, świadomych czy też nieświadomych schematów postępowania.

Wielu współczesnych autorów usiłuje dookreślić kategorię etosu, traktując ją opisowo, poprzez wskazanie charakterystycznych cech w postępowaniu określonych ludzi czy też grup zawodowych. Zbigniew Kwieciński tak ujął tę kategorię, pisząc, iż tworzy ona:

zrekonstruowany wzór (wzory) powtarzalnych i dominujących zachowań moralnych zbioru osób, przynależnych do określonej kategorii społeczno-kulturowej. [...] Etos jest efektem socjalizacji, wychowania i kształcenia oraz formowania osobowości, której składnikiem jest sumienie, kompetencja do dokonywania osądów i wyborów moralnych, zdolność do autorefleksji etycznej (Kwieciński, 20oo, s. 219).

Zatem, co możemy powiedzieć o etosie i elementach konstruujących go? Co możemy powiedzieć o tych, którzy sprowadzają edukację do poziomu czynnika wzrostu gospodarczego, a są jednocześnie funkcjonariuszami instytucji, którym przypisane jest „niesienie kaganka oświaty” czy może „kagańca oświaty"?

W tym kontekście ciekawie może zabrzmieć wypowiedź, jakiej udzielił wysoko postawiony w hierarchii akademickiej profesor, rektor Uniwersytetu Jagiellońskiego. Jednych może to oburzyć, inni być może zdobędą się na podziw dla tak śmiałej wypowiedzi. A mianowicie: 
przed paru laty głośna była autocharakterystyka jednego z profesorów Uniwersytetu Warszawskiego: „jestem dziwką”. Czyli: wynajmuję się za pieniądze do innych prac. A uczelnia staje się jedynie gigantyczną fabryką usług intelektualnych. [...] To tragiczny paradoks, że praca naukowa, która winna być prowadzona przede wszystkim w celu poszukiwania prawdy, staje się [...] drogą do zdobycia dodatkowego zatrudnienia. Został naruszony kanon etyczny obowiązujący w środowisku. Coraz częściej dowiadujemy się o przywłaszczeniu cudzych wyników naukowych, to znów - o bezceremonialnym przejęciu pomysłów badawczych (Romanowski, 1999).

\section{Edukacyjna racjonalność instrumentalna - konsumencka, czyli między etosem a pustym portfelem}

Edukacja w sytuacji konsumującej się gospodarki rynkowej, w tej nowej dla niej przestrzeni, ukazała swoje anarchiczne oblicze. Związane jest ono, jak pisze S. Ranson, z tym, że uczestnik rynku nie jest w stanie, jak w innych dziedzinach, formułować wcześniej swoich oczekiwań, które zostaną $\mathrm{w}$ procesie edukacyjnym przełożone na konkretne działania przy zachowaniu niezmiennych zewnętrznych warunków. Uczestnik tego rynku jest zmuszony dokonać „kalkulacji” na podstawie obcych głosów, nieobciążonych ich wewnętrznym namysłem nad realizacją przyjętych celów. Ta anarchiczność tworzy swoistą racjonalność, jaką kierują się bez wyjątku wszyscy uwikłani w przestrzeń rynkową, a więc: „dążenie do zaspokojenia materialnych interesów" (Ranson, 1997, s. 65). Racjonalnością tą kierują się edukatorzy, szkoły $i$ instytucje o charakterze edukacyjnym.

Anarchiczność rynku edukacyjnego ujawnia się w modelu jego funkcjonowania, w procesie „produkowania, wytwarzania określonego produktu”. W przypadku edukacji model ten nie odbiega od innych, według których funkcjonują np. przedsiębiorstwa produkcyjne. W systemie tym podmiotami gospodarującymi są instytucje edukacyjne oraz indywidualni edukatorzy, funkcjonariusze tychże instytucji. Motorem ich działania i akceleratorem jest dążenie do uzyskania wymiernych korzyści materialnych, koordynacja działań natomiast spoczywa w cenie, wartości oraz zapotrzebowaniu.

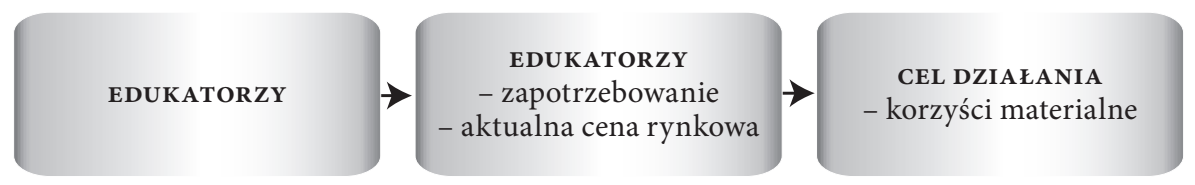

Schemat postępowania edukatorów na wolnym rynku

Źródło: opracowanie własne. 
Przedstawiony proces, obrazujący postępowanie edukatorów na wolnym rynku, odzwierciedla postępowanie rynkowe skierowane wprost na uzyskanie wymiernych korzyści materialnych. Postępowanie takie jest produktem posiadającym defekt partykularności, ograniczoną perspektywę.

Za Anthonym Giddensem można by powiedzieć, iż zaobserwowane zjawisko, w którym znaleźli się edukatorzy jako „wytwórcy” określonego produktu, ukazuje „dualność struktur”, a nawet pewną swoistą schizofreniczność. W ramach tej dualności uwidacznia się sytuacja, w której struktury gospodarcze stają się głównym elementem działania funkcjonariuszy instytucji edukacyjnych - edukatorów, oraz że te struktury polityki gospodarczej, choć w mniejszym stopniu, są wynikiem podejmowanych działań przez tychże funkcjonariuszy (Giddens, 2000, s. 26). Innymi słowy, sami sobie zgotowują taki los. Pamiętajmy, że perspektywa bycia funkcjonariuszem określonej instytucji, kojarząca się z bezrefleksyjnym powielaniem sposobów działania, nie wyklucza działań zmierzających do poszukiwania prawdy. Gdyż takie działania $\mathrm{z}$ jednej strony wpisane są w bycie człowiekiem, z drugiej strony, nawet jeżeli zakładamy, że działanie wynika z możliwej, na przykład, choroby psychicznej, u pacjenta można dostrzec przebłyski, które uwidaczniają się w momentach tak zwanego normalnego zachowania.

Udziałem funkcjonariuszy instytucji edukacyjnych w przestrzeni gospodarczej staje się faktycznie reprodukcja istniejących struktur oraz rezygnacja z roli, jaką de facto powinien pełnić edukator, poszukiwacz prawdy oraz pośrednik w jej przekazywaniu. Podporządkowuje się on wizji edukacji jako dziedziny "przemysłu”. Za taką wizją edukacji wydają się tęsknić niektórzy pracownicy naukowi, zwłaszcza uczelni technicznych, oraz przedstawiciele nauk ścisłych. W ich wyobrażeniu „edukacyjny biznes”, jako sposób modernizacji środowiska naukowego w oparciu o postulat pracy dla zysku, staje się mottem nie tylko dla samych edukatorów, lecz również w rozumieniu tychże edukatorów dla gospodarki.

\section{Edukacji ograniczenia demokratyczne}

Możemy w tym miejscu postawić pytanie: $w$ takim razie, $\mathrm{z}$ jaką relacją mamy do czynienia, w przypadku takich, a nie innych działań funkcjonariuszy instytucji edukacyjnych? Jak się mają w stosunku do siebie: naukowcy, dydaktycy, struktura państwa, oraz jakie konsekwencje ma faktyczne usytuowanie tych wszystkich elementów w płaszczyźnie polityki gospodarczej? Inne pytanie, jakie się jeszcze narzuca, to: czy edukacja ma wpływ na zjawisko nazywane, ogólnie rzecz biorąc, polityką? 
Z jednej strony, to właśnie „gospodarka” jest miejscem doceniania demokracji jako sposobu współistnienia wielu równorzędnych narracji, wołania o uznanie, z drugiej strony, to „demokracje” sprawują całkowicie kontrolę nad tym, co aktualnie dzieje się na rynku. Okazuje się, iż z tych zależności wyłaniają się daleko idące konsekwencje dla edukacji. O nich to pisze Stewart Ranson w Markets or Democracy for Education - Rynki CZy edukaCJA DLA DEMOKRACjI (Ranson, 1997, s. 77 i n.). Bezustanne ścieranie się tych dwóch potężnych płaszczyzn rynku i demokracji powoduje, że: edukacja nie może spełniać swojej roli, gdyż instytucje edukacyjne okazują się płaszczyzną niekończących się sporów o władzę; demokracja biurokratyzuje edukację w swoich strukturach, co jest przyczyną bezradności tej drugiej; w swojej krótkowzroczności rynek sprawia, iż edukacja konstruuje swoją ofertę wyłącznie na upodobaniach, modzie potencjalnych odbiorców, traktując ich jak zwykłych konsumentów, a siebie jako hurtownię towaru; edukacja wystawiona jest na wąską specjalizację, a tym samym zaawansowany proces selekcji i sortowania, który przeprowadzany w procesie praktycznej oceny „przydatności” kandydata może oznaczać „wulgarną komercjalizację i polityczną poprawność" (Bikont, 2000, s. 18-19). W efekcie mechanizmy rynkowe redukują edukację i uniemożliwiają rozwinięcie wszechstronnych możliwości jej oddziaływania. Jak napisał S. Ranson:

tak więc [rynek edukacyjny - dop. S.F.] pojawiając się po to, by dać wolność konsumentom, w rzeczywistości [...] obwarowuje się w głębszej i mniej wytłumaczalnej strukturze kontroli (Ranson, 1997, s. 78).

Dlatego też przestrzeń polityki gospodarczej zdaje się być niedoskonałą płaszczyzną funkcjonowania edukacji, gdyż z zasad, które tę przestrzeń mają regulować, wynika paradoks. Otóż, mechanizmy dążące do poszerzenia oferty na rynku edukacyjnym, a wpływające na jakość samego produktu, powodują „ograniczenie lub wykluczenie samego wyboru” (Ranson, 1997, s. 8o). Jak pisze dalej S. Ranson:

rynek nie może rozwiązać problemów, na jakie napotykamy: właściwie gwarantuje on, że pozbawieni zostajemy szansy ich rozwiązania. Problemy te - restrukturyzacja pracy, niszczenie środowiska, fragmentaryzacja społeczeństwa - stanowią kwestie tożsamości, zamożności, praw, wolności, możliwości i sprawiedliwości, które nie mogą być rozwiązane przez działające w izolacji jednostki ani przez wycofywanie się, ponieważ nie można być poza nimi. Rynki jedynie rozjątrzają te - publiczne z natury - problemy, a ponieważ dotyczą one nas wszystkich, cała społeczność może je analizować i uczestniczyć w ich rozwiązaniu (Ranson, 1997, s. 84$)$. 


\section{Konsumpcja jako medium w systemie polityki edukacyjnej}

Kolejnym pytaniem, które należy postawić, a odpowiedź, na które to pytanie może nam rozjaśnić relacje pomiędzy edukacją a szerszym kontekstem jej społeczno-politycznego funkcjonowania, będzie: czy edukacja, stanowiąc niewątpliwie jedną $\mathrm{z}$ wielu ofert gospodarczych, faktycznie posiada jakieś znaczenie polityczne, czyli formalnoprawne w sensie stanowienia społeczeństwa?

Niemiecki autor z połowy siedemnastego wieku - Chemnitz, w swoim dziele De Ratione status z 1647 roku pisał:

niejaka rozwaga polityczna wymagana w sprawach publicznych, radach i przedsięwzięciach, których jedynym celem jest zachowanie, rozszerzenie i pomyślność państwa dla realizacji zaś tego celu dobiera najłatwiejsze i najszybciej dostępne środki (Chemnitz, 1647).

Z tej to perspektywy przyglądając się edukacji, która wydaje się być łatwo dostępnym środkiem społecznych zmian, można mieć wrażenie jakoby miała ona dość poważne znaczenie w kreowaniu politycznego obrazu państw. To właśnie swoje kariery polityczne od reform edukacyjnych rozpoczęli Margaret Thatcher jako premier oraz Bill Clinton, reformując szkolnictwo stanu Arkansas i ogłaszając się rzecznikiem spraw oświaty. Na tym drobnym przykładzie można zaobserwować, że między polityką, rozumianą jako praktyka społeczna, a edukacją - wiedzą zachodzą wielorakie zależności. Jak to opisywała M. Kruczkowska w artykule zatytułowanym EDUKACJA CZY INWESTYCJA, już starożytni wiedzieli, że:

wiedza polityczna nie dotyczy uprawnień ludzkich ani praw ludzkich czy boskich, a tylko natury państwa, jakim należy rządzić. Rządzić można tylko wówczas, gdy znamy siłę państwa. Dzięki tej wiedzy można państwo utrzymać. Należy znać możliwości państwa i środki ich zwiększenia (Kruczkowska, 1993, s. 36).

Edukacja jako przekaz postępu naukowo-technicznego, czy też budowania relacji między społeczeństwem a innowacjami w dziedzinach tworzenia nowych technologii przemysłowych oraz wdrażania w owe technologie, na stałe wpisała się w sferę polityki oraz utrzymania współczesnego państwa. Edukacja może stać się próbą przewidywania oraz próbą projektowania przyszłości. Może ona nie wzbudzać euforii, rozważając niejednokrotnie ciemne scenariusze dla przyszłości świata, pomaga jednak, dzięki przewidywaniu zaistnienia najgorszych sytuacji, po prostu im zapobiegać, a tym samym przygotowywać społeczeństwa na wszelkie możliwości. Jak pisał Ulrich Beck: 
nowe autostrady, spalarnie śmieci, fabryki chemiczne, nuklearne czy biologiczne oraz instytuty badawcze napotykają opór bezpośrednio zainteresowanych grup ludności. Taki właśnie rozwój sytuacji, a nie radości z postępu (jak w początkach uprzemysłowienia) staje się obecnie łatwy do przewidzenia (Beck, 1994, s. 28).

Wszechobecny rynek ofiarował społeczeństwu specyficzne, polityczne narzędzie pomiaru wszelkiego rodzaju działań. Narzędziem tym jest wydajność ekonomiczna. Tak samo jak produkcja, w przypadku edukacji:

Kalkuluje się, w jaki sposób inwestycja zwróci się na rynku pracy, ile będzie kosztowało zaniedbywanie inwestycji w walce z konkurencją lepiej wykształconej siły roboczej. Postrachem rodziców amerykańskich jest dziecko japońskie, które spędza w szkole o 60 dni w roku więcej od swojego rówieśnika ze Stanów. Edukacja jest uważana za jeden z głównych sposobów długodystansowej walki z recesją, więc rządy i korporacje nie skąpią na nią pieniędzy (Kruczkowska, 1993, s. 36).

Zwolennicy perspektywy gospodarczej, idealizujący jej zasługi w kreowaniu społeczeństwa oraz zachwyceni zasadami zarządzania zasobami ludzkimi, zdolnościami, wiedzą, wydają się nie zauważać, że to właśnie rynek ekonomiczny wytwarzający egoistyczne zachowania klientów działa według zasady:

rozwój musi odbywać się kosztem innych. Ważne jest tu to, że nie tyle jednostki są z natury egoistycznie zorientowane na własne interesy, ale że to instytucje rynku takimi je czynią (Ranson, 1997, s. 81).

\section{Wnioski, czyli edukacja w perspektywie konsumującego się egoizmu}

Wniosek pierwszy: wielu nauczycieli akademickich „sprzedających” swoją wiedzę $\mathrm{w}$ ramach funkcjonowania edukacyjnego rynku komercyjnego, zgodnie artykułuje swoje opinie co do tego, że gospodarka znalazła w ich środowisku bardzo podatny grunt dla popularyzowania swojej użytkowej racjonalności.

Wniosek drugi: rynkowa racjonalność zaczęła stanowić źródłową racjonalność rozbudowy nauki, prowadzącą do redukcji innych racjonalności, między innymi historycznej czy humanistycznej. Dla niektórych dyscyplin stanowi to przynętę mogącą wygenerować, mówiąc słowami P. Feyerabenda „naukowy szowinizm”, pragnący stać się regułą życia społecznego (Feyerabend, 1976, s. 308).

Wniosek trzeci: wzajemne oddziaływanie edukacji jako rynku, wraz z jego oferowanymi produktami, mechanizmami regulującymi wewnętrzną dynamikę, oraz systemów politycznych na świecie, stało się faktem. 
Wniosek czwarty: rynek edukacyjny wydaje się jednak posiadać jeszcze inną racjonalność, niemieszczącą się jednocześnie w klasycznym rynkowym schemacie podaży i popytu. Ta wspominana racjonalność edukacji będącej zinstytucjonalizowanym, akceptowanym oraz stanowionym przez prawo organem władzy, kształtuje społeczny podział obowiązków, a co za tym idzie „namaszcza” współczesnych wykonawców władzy. W sytuacji tej, edukacja może ograniczać się do kreowania reprezentantów społeczeństwa tworząc swoisty image „panowania specjalistów” lub „panowania elit”.

Wniosek piąty: w działaniu instytucji edukacyjnych jako uczestników gry gospodarczej i oferujących specjalistyczne usługi dostrzegamy różnorodne cele, do jakich one zmierzają. Są to, między innymi, rozwijanie stosunków rywalizacji, regulacja stosunków społeczno-politycznych za pomocą upowszechniania zjawiska „wycofywania się”, jako próby świadomego podejmowania decyzji poza płaszczyzną dobra ogólnego. Jak to napisał Heinrich Kupffer - profesor, pedagog zaangażowany w Ruchu Obrony Praw Dziecka w Niemczech:

konsumenci nie mogą wyrazić wprost niechęci wobec czegoś, jak tylko przez wycofywanie się i alternatywny zakup (Kupffer, 1980, s. 27).

Wniosek szósty: edukacja uwikłana w działania polityki gospodarczej staje się jednym $\mathrm{z}$ mechanizmów spychających używanie argumentów racjonalnych, uwzględniania priorytetów w procesie formułowania sądów o tym, co jest dobrem ogólnym.

\section{BIBLIOGRAFIA}

Beck, U., Giddens, A., Lash, S. (1994). Reflexive Modernization: Politics, Tradition and Aesthetics in the Modern Social Order. Stanford, CA: Stanford University Press.

Bikont, A. (2000). Komandosi edukacji. Rozmowa z prof. Jerzym Axerem. Gazeta Wyborcza, 18-19 XI, s. 20.

Bourdieu, P., Boltanski, L., Castel, R., Chamboredon, J. C. (1967). Un art moyen. Essai sur les usages sociaux de la photographie. Revue française de sociologie, T. 8, nr 2, s. 259.

Chemnitz, B. P. von. (1647). Dissertatio De Ratione Status In Imperio Nostro Romano-Germanico. Freistadii (i.e. Amsterdam).

Feyerabend, P. (1976). Wider den Methodenzwang - Skizze einer anarchistischen Erkenntnistheorie. Frankfurt am Main: Suhrkamp Verlag.

Foucault, M. (1995). Polityczne technologie jednostki. Odra, nr 4.

Futyma, S. (2001). Wolnego rynku implikacje dla edukacji. Toruń: Wydawnictwo „Edytor”.

Giddens, A. (1984). The Constitution of Society. Outline of the Theory of Structuration. Berkeley: University of California Press.

Haremska, K. (1994). Zło kapitalizmu. W: M. Kuniński (red.), Filozofia wolnego rynku. Kraków: Wydawnictwo Znak. 
Kapralski, S. (1992). Racjonalność i perspektywy socjologii wiedzy. Między rozumem niepokalanym a rozumem uwikłanym. W: H. Kozakiewicz, E. Mokrzycki, M. J. Siemek (red.), Racjonalność współczesności. Warszawa: PWN.

Kłoskowska, A. (1990). Teoria socjologiczna Pierre’a Bourdieu. W: P. Bourdieu, J.-C. Passeron, Reprodukcja. Elementy teorii systemu nauczania. Warszawa: Wydawnictwo Uniwersytetu Warszawskiego.

Kozakiewicz, H., Mokrzycki, E., Siemek, M. J. (red.). (1992). Racjonalność współczesności. Warszawa: PWN.

Kruczkowska, M. (1993). Edukacja czy inwestycja. Społeczeństwo Otwarte, nr 4.

Kuniński, M. (red.). (1994). Filozofia wolnego rynku. Kraków: Wydawnictwo Znak.

Kupffer, H. (1997). Erziehnung - Angriff auf die Feigheit. Essay gegen Pädagogik die den Lebensweg des Menschen mit Hinweisscholdern umstellt. Beltz.

Kwieciński, Z. (200o). Etos środowiska akademickiego pedagogów. Patologia czy rozwój? W: I. Wojnar (red.), Etos edukacji w XXI wieku. Warszawa: Elipsa.

Macpherson, C. B. (1973). Democratic Theory: Essays in Retrieval. Oxford: Clarendon Press.

Marina, J. A. (2010). Porażka inteligencji czyli Głupota w teorii i praktyce. Kraków: WAM.

Marody, M. (red.). (20oo). Między rynkiem a etatem. Społeczne negocjowanie polskiej rzeczywistości. Warszawa: Wydawnictwo Naukowe „Scholar”.

Ranson, S. (1997). Rynki czy demokracja dla edukacji. W: Z. Kwieciński (red.), Nieobecne dyskursy. T. V, Toruń: UMK.

Romanowski, A. (1999). Uniwersytet na wolnym rynku. Rozmowa z rektorem UJ prof. Franciszkiem Ziejką. Tygodnik Powszechny, nr 41.

Strawiński, P. (2015). Japonia rezygnuje ze studiów humanistycznych i społecznych. Pozyskano z: http://kariera.forbes.pl/japonia-rezygnuje-ze-studiow-humanistycznych-i-spolecznych, artykuly,199094,1,1.html, [data dostępu: 23.10.2015].

Titmuss, R. M. (1971). The Gift Relationship: Forum Human Blood to social Policy. London: Oxford University Press.

\section{SUMMARY}

\section{About some aspects of the educational ethos and consumption}

The article describes the changes in the attitude of scholars. These changes relate to the understanding of what knowledge is, and therefore which purposes this knowledge serves. This text draws attention to the fact that often the decisive element in the value of transferred knowledge is the economic factor. This modern utilitarianism, appropriated people with their ambitions and skills. Thus, in this reflection, we find discussion about the value of knowledge, scholars' attitudes, the role and place of education in the modern world, and factors that modify the shape of modern education and its officers such as: selfishness or consumer rationality.

KEY WORDS: education, consumption, educational ethos, educational market. 